\title{
Microcalorimetric studies of the heats of solution of bovine myelin basic protein
}

\author{
Cynthia S. Randall and Robert Zand * \\ Macromolecular Research Center, Biophysics Research Division, Institute of Science and Technologv, and Department of \\ Biological Chemistry, The University of Michigan, Ann Arbor, MI 48109 (U.S.A.)
}

(Received March 6th, 1985)

Key words: Myelin basic protein; Thermodynamics; Calorimetry; (Bovine)

\begin{abstract}
Heats of solution for myelin basic protein have been determined using microcalorimetry. All aqueous systems studied yielded negative heats of solution; in contrast, trifluoroethanol produced a small positive heat of solution, while reaction with dimethyl sulfoxide was strikingly exothermic. The heat of interaction for native myelin basic protein with $8 \mathrm{M}$ urea at $\mathrm{pH} 4.0,29^{\circ} \mathrm{C}$, was found to be $-79 \pm 16 \mathrm{kcal} / \mathrm{mol}$. The significance of these results in terms of the protein's structural organization is discussed.
\end{abstract}

\section{Introduction}

Myelin basic protein is a major protein constituent of both the central nervous system and peripheral nervous system myelin sheaths, and has been extensively studied with regard to its disease-inducing properties [1]. Because the protein has an unusually high proportion of basic amino acids and lacks any clear extended hydrophobic sequence in its primary structure, myelin basic protein is often assumed to behave as a random coil or 'denatured' protein in aqueous solution [2]. But theoretical predictions suggest that regions of organized structure may be present in myelin basic protein, particularly $\beta$-turn and $\beta$-sheet topologies $[3,4]$. Experimental results from fluorescence spectroscopy $[5,6]$ and nuclear magnetic resonance measurements $[7,8]$ also support the existence of such regions within native myelin basic protein.

This laboratory has had a long-standing program of investigating the solution structure and behavior of myelin basic protein [9-11]. Microcalorimetry, a technique not previously applied to

\footnotetext{
* To whom correspondence should be addressed.
}

study these aspects of myelin basic protein, appears potentially helpful in this regard. One parameter of interest is the heat of solution or enthalpy, which characterizes the interaction of a protein with its solvent. By measuring the heat of solution in different solvents at constant temperature, the heat of transfer for the protein between the media can be determined. This approach can be applied to study protein denaturation as well as other conformational changes; representative methods and results have been reviewed by Brown [12].

In the present study, heats of solution were obtained for myelin basic protein under a variety of conditions. In addition to aqueous media, two nonaqueous solvents were chosen: the $\alpha$-helix promoting agent trifluoroethanol, and dimethyl sulfoxide. The heat of interaction of myelin basic protein with a denaturing agent was calculated by difference from the heats of solution produced in the presence and absence of $8 \mathrm{M}$ urea in aqueous buffer. The details of the microcalorimetric measurements and the evaluation of the data are presented in order to provide additional documentation to support the contention that myelin basic protein in vitro is not a denatured protein. 


\section{Materials and Methods}

Myelin basic protein was purified from bovine brains and spinal cords according to the procedure of Deibler et al. [13]; polyacrylamide gel electrophoresis was used to verify purity. Lyophilized myelin basic protein was stored at $-20^{\circ} \mathrm{C}$ prior to use. For microcalorimetric experiments, approx. $10 \mathrm{mg}$ of pure myelin basic protein was first pressed in a $\mathrm{KBr}$ pellet die at $5000 \mathrm{lb} /$ inch $^{2}$, carefully cut to fit into the sample pan and then weighed before inserting the pan into the calorimeter cell.

Enthalpy measurements were performed using a modified Tian-Calvet microcalorimeter at $29^{\circ} \mathrm{C}$; a detailed description of this type of instrument is given by Maron and Filisko [14]. The two calorimeter cells were electrically calibrated as described by Kogowski et al. [15]. The resulting plots of heat output versus measured curve area (Fig. 1) showed good linearity.

In these experiments, a two-tube cell assembly schematically diagrammed in Fig. 2 was utilized. The outer glass tube, $4 \mathrm{~mm}$ in diameter, fits tightly into the Teflon cap of the stainless steel calorimeter cell, and is used to lift the assembly in and out of the microcalorimeter. The inner glass rod, $2 \mathrm{~mm}$ in diameter, extends into the cell; attached to this end is a cover for the sample pan. At the bottom of the cell, the cover is centered on top of the pan

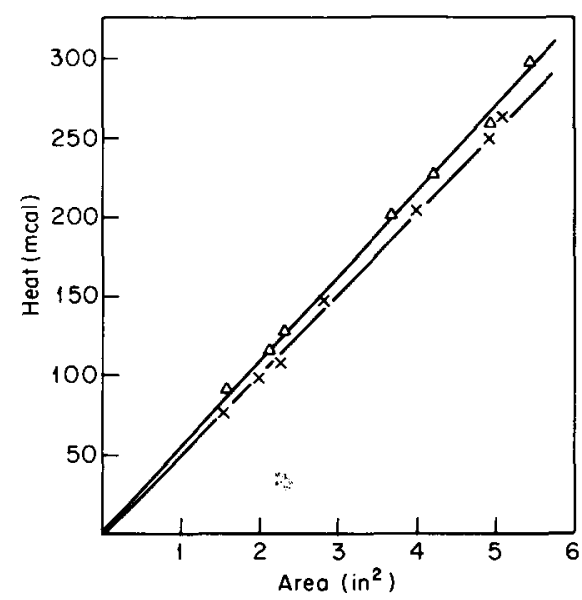

Fig. 1. Calibration for cell $1(X)$ and cell $2(\Delta)$. Both cells show a linear response of the microcalorimeter to heat generated by a calibrating resistor.

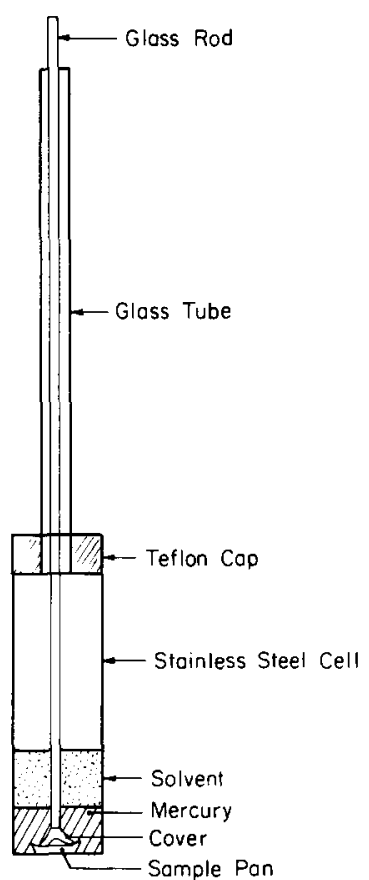

Fig. 2. Calorimeter two-tube cell assembly.

containing the solid myelin basic protein sample. Weights are attached to the top of the rod to prevent the sample pan from floating upward while mercury is measured into the cell. The desired amount of solvent is then pipetted on top of the mercury and the cell is closed by tightly screwing the Teflon cap. The same procedure is repeated for the other cell, using identical amounts of mercury and solvent.

After lowering the cells into the calorimeter, they were allowed to equilibrate for $3 \mathrm{~h}$. Upon obtaining a steady baseline on the chart recorder, reaction in one cell was initiated by slowly raising the inner rod with a synchronous motor. The resulting recorded curve can be converted to an enthalpy value using the previously determined cell calibration constants and the known myelin basic protein sample weights. In general, several dissolutions of myelin basic protein with a given solvent were recorded, and the enthalpy values were averaged. In order to minimize errors in measurements, great care must be exercised in handling and loading the calorimeter cells. Cleanliness and dryness of the cells, glass tubing, sample pans, and mercury are important factors in reproducibility. 
Differential scanning calorimetry studies on myelin basic protein were performed on a PerkinElmer DSC-2B calorimeter interfaced to a thermal analysis data station. Typically $50 \mu \mathrm{l}$ of solution were pipetted into stainless steel capsules, which were then hermetically sealed. Capsules containing the buffer of interest were placed in the reference and sample cell holders, and heated from 20 to $100^{\circ} \mathrm{C}$ to observe the instrument baseline and make any necessary adjustments. A capsule containing myelin basic protein, $3-5 \%(\mathrm{w} / \mathrm{v})$ in the same buffer, was then inserted into the sample cell holder and heated after equilibration with the reference buffer capsule. Samples were cooled and rescanned several times to assess the reversibility of observed transitions.

\section{Results and Discussion}

\section{Heats of solution of myelin basic protin}

Heat of solution values for myelin basic protein in various solvents are given in Table $I$, with representative heat output curves shown in Figs. 3 and 4 . From the data, the following observations can be made: First, as expected, $\Delta H_{\mathrm{soln}}$ for myelin basic protein in water is markedly exothermic. Replacement of $\mathrm{H}_{2} \mathrm{O}$ with ${ }^{2} \mathrm{H}_{2} \mathrm{O}$ or with a dilute buffer also produces exothermic values, although the variation in $\Delta H_{\text {soln }}$ for ${ }^{2} \mathrm{H}_{2} \mathrm{O}$ is larger than expected. However, recent calorimetric studies on phycocyanins indicate that ${ }^{2} \mathrm{H}_{2} \mathrm{O}$ can exert signifi-

\section{TABLE I}

$\triangle H_{\text {II }}$ VALUES FOR THE REACTION OF SOLID MYELIN BASIC PROTEIN WITH VARIOUS SOLVENTS AT $29^{\circ} \mathrm{C}$

Mean values are given, followed by the standard deviations.

\begin{tabular}{ll}
\hline Solvent & $\Delta H_{\text {soln }}(\mathrm{kcal} / \mathrm{mol})$ \\
\hline $\mathrm{H}_{2} \mathrm{O}$ & $-91 \pm 3$ \\
${ }^{2} \mathrm{H}_{2} \mathrm{O}^{\mathrm{a}}$ & $-58 \pm 1$ \\
$\mathrm{Buffer}^{\mathrm{b}}$ & $-74 \pm 6$ \\
$\mathrm{CF}_{3} \mathrm{CH}_{2} \mathrm{OH}$ & $+22 \pm 1$ \\
$\left(\mathrm{CH}_{3}\right)_{2} \mathrm{SO}$ & $-209 \pm 11$ \\
$\mathrm{Buffer}{ }^{\mathrm{b}}+8 \mathrm{M}$ urea & $-153 \pm 12$ \\
\hline
\end{tabular}

a Prior to measurement, solid myelin basic protein samples were repeatedly dissolved and lyophilized in ${ }^{2} \mathrm{H}_{2} \mathrm{O}$ to deuterate the exchangeable protons.

${ }^{\text {h }}$ Buffer is $0.05 \mathrm{M}$ sodium acetate $(\mathrm{pH} 4.0$ ).
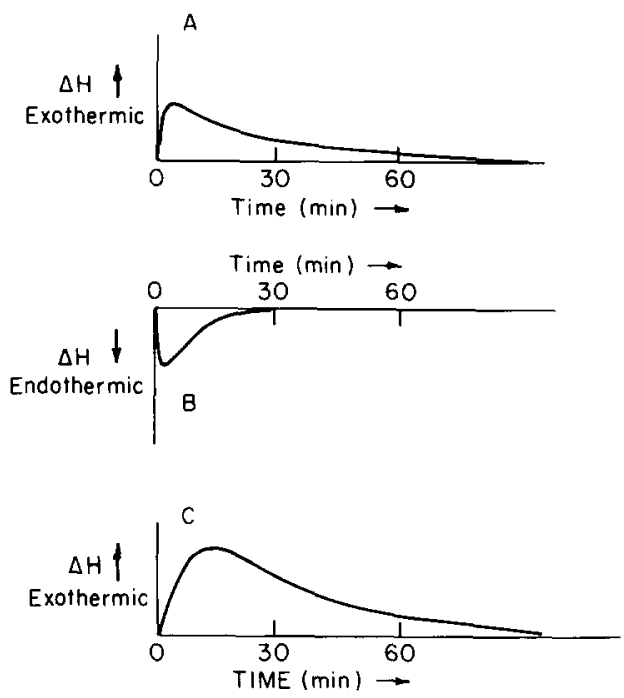

Fig. 3. Tracings of representative recorder outputs produced when solid myelin basic protein is mixed with identical amounts of different solvents. Data were recorded at $10 \mu \mathrm{V}$ sensitivity with a chart speed of $2.5 \mathrm{in} / \mathrm{h}$. (A) $5.59 \mathrm{mg}$ in $\mathrm{H}_{2} \mathrm{O}$. (b) $6.79 \mathrm{mg}$ in $\mathrm{CF}_{3} \mathrm{CH}_{2} \mathrm{OH}$. (c) $5.67 \mathrm{mg}$ in $\left(\mathrm{CH}_{3}\right)_{2} \mathrm{SO}$.

cant effects on the structure and stability of native proteins [16]. Such effects may reflect changes in hydrophobic interactions as well as in hydrogenbonding properties when $\mathrm{H}_{2} \mathrm{O}$ is replaced by ${ }^{2} \mathrm{H}_{2} \mathrm{O}$ as the solvent. In a calorimetric study of ribonuclease hydration, Almog and Schrier [17]
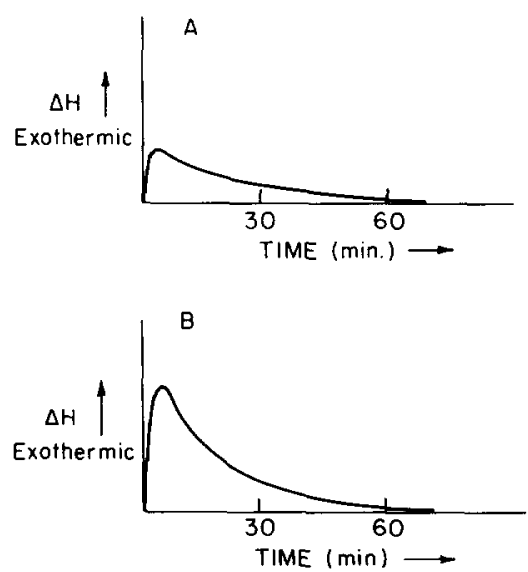

Fig. 4. Tracings of representative recorder produced when solid myelin basic protein is mixed with identical amounts of different solvents. Data were recorded at $10 \mu \mathrm{V}$ sensitivity with a chart speed of $2.5 \mathrm{in} / \mathrm{h}$. (A) $7.37 \mathrm{mg}$ in $0.05 \mathrm{M}$ sodium acetate (pH 4.0). (b) $7.45 \mathrm{mg}$ in same buffer containing $8 \mathrm{M}$ urea. 
detailed the exothermic contributions to $\Delta H_{\text {soln }}$. The major effect results from the solvation of charged and other polar surface sites by water upon dissolution of the protein; this process opposes the weaker protein-protein interactions in the solid phase.

The interpretation of $\Delta H_{\text {soln }}$ values for myelin basic protein in non-aqueous solvents is less straightforward at present, in part because calorimetric data on other proteins in such solvents are lacking. An additional complication is the fact that $\Delta H_{\text {soln }}$ is actually made up of several enthalpy components:

$\Delta H_{\text {soln }}=H_{\text {soln.final }}-\left(H_{\text {solute }}+H_{\text {solvent }}\right)$

$H_{\text {solute }}$ can be further broken down to reflect enthalpy contributions from the structured and unfolded forms of the solute:

$H_{\text {solute }}=H_{\text {structured }}+H_{\text {unfolded }}$

Substituting this expression into the expression for $\Delta H_{\text {soln }}$ gives

$\Delta H_{\mathrm{soln}}=H_{\mathrm{soln} \text {.final }}-\left(H_{\text {structured }}+H_{\text {unfolded }}+H_{\text {solvent }}\right)$

which can be rewritten as

$\Delta H_{\text {soln }}=H_{\text {soln final }}-\left(H_{\text {unfolded }}+H_{\text {solvent }}\right)-H_{\text {structured }}$

The first three enthalpy terms are frequently combined into a single term called the heat of mixing. In the present experiments, $H_{\text {soln.final }}$ and $H_{\text {solvent }}$ are expected to depend greatly on the solvent system used; a knowledge of $H_{\text {solvent }}$, at least on a relative scale, must be available for a detailed analysis of solute-solvent interactions. In the absence of this knowledge, interpretation of the experimental results is therefore restricted.

However, there are some related theoretical and experimental studies involving small model compounds, which have been reviewed by Brown [12]. One important force in stabilizing secondary and tertiary structure in proteins is the hydrogen bond. In aqueous media, polar groups on the protein can form multiple hydrogen bonds with water. The structural stabilization imparted by hydrogen bonding can be enhanced or disrupted by the interactions of various amino acid side-chains.
These interactions can be electrostatic or hydrophobic in nature; the latter type of association appears to be especially important in stabilizing the folded configuration of many proteins. Calorimetric studies must thus consider the competing effects of solute polarity (i.e., the highly polar charge bearing portions of the molecule vs. the nonpolar side chains) and their relation to structural ordering or a given solvent.

As an example, let us consider the coil-to-helix transition of poly ( $\gamma$-benzyl-L-glutamate) (PBG) in ethylene dichloride/dichloroacetic acid (DCA) mixtures, which has been calorimetrically analyzed by Ackermann [18]. The overall reaction is endothermic, but can be broken down into various enthalpy components: a negative enthalpy (exothermic process), resulting from the formation of intramolecular helix stabilizing hydrogen bonds; a positive enthalpy change (endothermic process) due to the disruption of intermolecular hydrogen bonds between DCA and amide groups of the polypeptide; and an additional negative enthalpy change is produced by dimerization of DCA molecules released from PBG as the coil-to-helix transition progresses.

In the present case, spectroscopic methods have convincingly demonstrated that both trifluoroethanol and dimethyl sulfoxide induce structural perturbations in myelin basic protein, and this is undoubtedly reflected in the observed $\Delta H_{\text {soln }}$ values. Trifluoroethanol promotes $\alpha$-helix formation in myelin basic protein [9]; this transition is expected to contribute an exothermic enthalpy value akin to that discussed for PBG. But other processes involving hydrophobic and hydrophilic regions of myelin basic protein probably also contribute to the overall $\Delta H_{\text {soln }}$ which is in fact slightly endothermic.

Dimethyl sulfoxide has strikingly different effects on myelin basic protein solvation. The $\Delta H_{\text {soln }}$ is highly exothermic, although the shape of the recorded curve indicates that solution occurs more slowly than in aqueous media. Some proton NMR studies on myelin basic protein peptide fragments in DMSO- $d_{6}$ have suggested that this solvent promotes intermolecular hydrogen-bond formation [19]; it has also been implicated in stabilization of $\beta$-turn regions [20]. NMR data on intact myelin basic protein in DMSO are limited by aggregation 
effects, but the conformation of myelin basic protein is expected to be quite different from that in water as well as the one in trifluoroethanol, which is predominantly $\alpha$-helical.

Heat of interaction for myelin basic protein with urea

The enthalpy of interaction $\Delta H_{\text {int }}$ for myelin basic protein with urea was determined by measuring $\Delta H_{\text {soln }}$ with and without $8 \mathrm{M}$ urea under otherwise identical conditions. The magnitude and sign of $\Delta H_{\mathrm{int}}$ for myelin basic protein, -79 $\mathrm{kcal} / \mathrm{mol}$, agree well with the $\Delta H_{\mathrm{int}}$ values obtained by other investigators for various globular proteins in concentrated urea solutions $[21,22]$. It should be noted that, like $\Delta H_{\text {int }}$ for myelin basic protein, those $\Delta H_{\text {int }}$ values also reflect a relatively large degree of uncertainty and should be considered as estimates rather than exact values.

The mechanism of protein denaturation by urea has been a topic of considerable discussion [23]. One proposal is that urea perturbs the structure of water, thereby reducing intramolecular hydrophobic forces which stabilize the native protein [24]. An alternative explanation is that such intramolecular bonds are broken when urea forms intermolecular hydrogen bonds with the protein [25]. From the calorimetric studies of proteins as well as of oligopeptides in urea solutions [26], there is now little doubt that urea binding to the peptide bond makes the largest enthalpy contribution; the enthalpy of this interaction is large and negative.

The interaction of a native protein with a denaturing agent such as urea can be described using the notation of Lapanje [27]:

$\Delta H_{\mathrm{otr}}=\Delta H_{\mathrm{tr}, \mathrm{D}}+\Delta H_{\mathrm{D}}^{\circ}$

where $\Delta H_{\text {otr }}$ is the overall enthalpy of transfer, $\Delta H_{\text {tr. }}$ is the enthalpy of solvation for the denatured protein, and $\Delta H_{\mathrm{D}}^{\circ}$ is the enthalpy of unfolding for the protein as it goes from the native to denatured state. As previously mentioned, $\Delta H_{\text {tr. D }}$ is expected to be highly exothermic, while $\Delta H_{\mathrm{D}}^{\circ}$ is predicted to be endothermic and somewhat smaller in magnitude.

$\Delta H_{\text {tr. D }}$ can also be defined as a sum of enthal- pies of the individual amino acid constituents present in a protein:

$\Delta H_{\mathrm{tr}, \mathrm{D}}=\sum \alpha_{i} n_{i}^{\circ} \delta h_{\mathrm{tr} .}$

where $\alpha_{i}$ is a fractional quantity associated with exposure to the solvent [28], $n_{i}^{\circ}$ is the total number of groups of type $i$ present in the protein and $\delta h_{\mathrm{tr}, i}$ is the enthalpy of transfer of a group from water to aqueous denaturant solution. As shown in Table II, $\delta h_{\mathrm{tr}, i}$ values have been determined experimentally from calorimetric studies on amino acids and oligopeptides [26,29]; however, $\delta h_{\mathrm{tr}, i}$ values for most amino acids remain unavailable and are estimated in order to calculate $\Delta H_{\text {tr.D }}$ [27]. Thus the calculated value of $\Delta H_{\mathrm{tr}, \mathrm{D}}$ should be

TABLE II

ENTHALPIES OF TRANSFER OF THE CONSTITUENT GROUPS OF BOVINE MYELIN BASIC PROTEIN FROM WATER TO CONCENTRATED UREA SOLUTIONS AT $25^{\circ} \mathrm{C}$

\begin{tabular}{|c|c|c|c|c|}
\hline Group & $\begin{array}{l}\delta h_{\mathrm{tr}, i} \\
(\mathrm{cal} / \\
\mathrm{mol})\end{array}$ & $n_{i}^{\circ}$ & $\alpha_{r}{ }^{b}$ & $\begin{array}{l}\Delta H_{\mathrm{tr} . \mathrm{D}} \\
(\mathrm{cal} / \\
\mathrm{mol})\end{array}$ \\
\hline Peptide unit ${ }^{c}$ & \multirow[t]{9}{*}{-910} & 168 & - & -152880 \\
\hline $\operatorname{Ala}(1 / 3 \mathrm{Val})^{d}$ & & 14 & 0.48 & 1505 \\
\hline $\operatorname{Arg}(\text { Leu }+1 / 2 \text { Gly })^{d}$ & & 18 & 0.24 & 1344 \\
\hline Asn (Ala) ${ }^{d}$ & & 2 & 0.23 & 103 \\
\hline $\operatorname{Asp}(1 / 2 \text { Gly })^{d}$ & & 9 & 0.23 & -942 \\
\hline Gln (2 Ala) ${ }^{d}$ & & 8 & 0.24 & 860 \\
\hline Glu (Ala $+1 / 2$ Gly) ${ }^{d}$ & & 2 & 0.24 & -111 \\
\hline His (Val) ${ }^{d}$ & & 10 & 0.17 & 1142 \\
\hline Ile (Leu) & & 3 & 0.27 & 620 \\
\hline Leu & \multirow[t]{3}{*}{766} & 10 & 0.25 & 1915 \\
\hline Lys (Leu $+1 / 2$ Gly) ${ }^{d}$ & & 13 & 0.27 & 1092 \\
\hline $\operatorname{Met}(2 \text { Ala })^{d}$ & & 2 & 0.28 & 251 \\
\hline Phe & \multirow[t]{6}{*}{181} & 8 & 0.18 & 261 \\
\hline $\operatorname{Pro}(3 / 4 \mathrm{Val}){ }^{\mathrm{d}}$ & & 12 & 0.25 & 1512 \\
\hline $\operatorname{Ser}\left(\right.$ Ala) ${ }^{d}$ & & 18 & 0.32 & 1290 \\
\hline Thr (Val) ${ }^{d}$ & & 7 & 0.28 & 1317 \\
\hline Trp (Phe) ${ }^{d}$ & & 1 & 0.17 & 31 \\
\hline Tyr (Phe) & & 4 & 0.24 & 174 \\
\hline \multirow[t]{2}{*}{ Val } & 672 & 3 & 0.27 & 544 \\
\hline & & & \multicolumn{2}{|c|}{ Total $=-139972$} \\
\hline
\end{tabular}

a Data obtained from Refs. 26 and 29.

${ }^{h}$ Data obtained from Ref. 28.

" Unit defined as $\mathrm{CH}_{2}-\mathrm{CO}-\mathrm{NH}$ (Ref. 23).

d Data not available; estimates are made based on characteristics of the side-chain with respect to those of group(s) in parentheses (Ref. 27). 
considered as an approximation, rather than an exact value. Carrying out the summation of enthalpies for the amino acid sequence of bovine myelin basic protein [30] yielded a value of -140 $\mathrm{kcal} / \mathrm{mol}$; as anticipated, the value is markedly exothermic.

Let us now consider $\Delta H_{\mathrm{D}}^{\circ}$. Enthalpies of unfolding have been obtained for several globular proteins under a variety of conditions using thermodynamic as well as optical methods $[12,18,31$, 32]. Most, though not all, of these proteins appear to satisfy the two-state transition model, i.e., native $\rightarrow$ denatured. Whether myelin basic protein also behaves in this way is unclear; it obviously lacks the degree of structural organization known to be present in globular proteins. However, highresolution NMR data on myelin basic protein and its pepetide fragments in aqueous media indicate that both temperature and denaturing agents selectively effect the chemical shifts [7,19]. Also, if the previously discussed numerical values for $\Delta h_{\text {otr }}$ and $\Delta H_{\mathrm{tr}, \mathrm{D}}$ are substituted into the equation

$\Delta H_{\mathrm{D}}^{\circ}=\Delta H_{\text {orr }}-\Delta H_{\text {tr. }}$

a value of $61 \mathrm{kcal} / \mathrm{mol}$ is obtained for $\Delta H_{\mathrm{D}}^{\circ}$. Admittedly, this value contains a relatively large

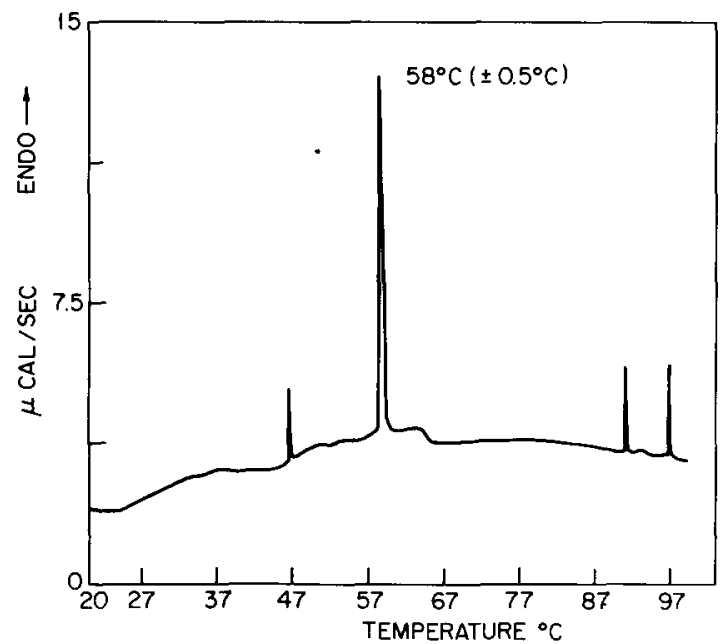

Fig. 5. DSC thermogram for myelin basic protein $(45 \mathrm{mg} / \mathrm{ml})$ in $0.05 \mathrm{M}$ sodium acetate buffer, $\mathrm{pH} 4.2$. Heating rate was 1.25 $\mathrm{C} \mathrm{deg} / \mathrm{min}$. The major endotherm at $58^{\circ} \mathrm{C}$ was assigned to myelin basic protein unfolding. At present it is unclear whether the minor endotherms result from additional perturbations of myelin basic protein structure, or whether they represent impurities still present after protein purifications (see ref. 6). degree of uncertainty and represents only a crude approximation. However, it is clearly endothermic, as predicted, and falls within the range of unfolding enthalpies determined experimentally for other proteins $[18,31]$.

Furthermore, preliminary differential scanning calorimetry data on myelin basic protein at $\mathrm{pH} 4$ (Fig. 5) indicate that the protein undergoes a reversible transition at $58^{\circ} \mathrm{C}$, which would seem to be consistent with unfolding. At $\mathrm{pH} 8$, the transition appears to be substantially suppressed; this particular observation tends to support the results of a previous DSC study on myelin basic protein, in which no transitions were observed at $\mathrm{pH} 7.4$ [33]. The basis for the apparent $\mathrm{pH}$ dependence is unclear; it may reflect contributions of certain charged amino acid side-chains on myelin basic protein, as well as the demonstrated ability of myelin basic protein to self-associate above $\mathrm{pH} 7$ [34]. Further calorimetric studies on myelin basic protein as a function of $\mathrm{pH}$, concentration and temperature may provide more information on the mechanism of unfolding in this protein.

\section{Conclusion}

The microcalorimetric data presented here serve as a starting point in characterizing thermodynamic aspects of myelin basic protein, particularly in relation to the protein's conformation. The protein is sensitive to changes in the solvent environment, as evidenced by strikingly different $\Delta H_{\text {soln }}$ values. Studies of the interaction of myelin basic protein with urea, combined with theoretical calculations and preliminary DSC data, indicate that the protein has elements of well-defined secondary structure in aqueous acid media and can be denatured in much the same way as can globular proteins.

\section{Acknowledgements}

We wish to thank Dr. F.E. Filisko for use of the modified Tian-Calvet microcalorimeter, as well as for helpful discussions. We also thank Dr. Z. Jiang and Dr. S. Govil for assistance with the DSC measurements. This work was supported in part by a grant from the National Science Foundation, BNS 7904381. 


\section{References}

1 Day, E.D. (1981) Contemp. Topics Mol. Immunol. 8, 1-39

2 Martenson, R.E. (1980) in Biochemistry of Brain (Kumar, S., ed.), pp. 49-79, Pergamon Press, Oxford

3 Martenson, R.E. (1981) J. Neurochem. 36, 1543-1560

4 Stoner, G.L. (1984) J. Neurochem. 43, 433-447

5 Jones. A.J.S. and Epand, R.M. (1980) Biochim. Biophys. Acta $625,165-178$

6 Randall, C.S. and Zand, R. (1985) Biochemistry 24, 1998-2004

7 Chapman, B.E., Littlemore, L.T. and Moore, W.E. (1978) Adv. Exp. Med. Biol. 100, 207-220

8 Mendz, G.T., Moore, W.J. and Carnegie, P.R. (1982) Biochem. Biophys. Res. Commun. 105, 1333-1340

9 Liebes, L.F., Zand, R. and Phillips, W.D. (1975) Biochim. Biophys. Acta 405, 27-39

10 Liebes, L.F., Zand, R. and Phillips, W.D. (1976) Biochim. Biophys. Acta 427, 392-409

11 Zand. R. and Agrawal, K. (1980). Trans. Am. Soc. Neurochem. 11,242

12 Brown, H.D. (1971) J. Agr. Food Chem. 19, 669-678

13 Deibler, G.E., Martenson, R.E. and Kies, M.W. (1972) Prep. Biochem. 2, 139-165

14 Maron, S.H. and Filisko, F.E. (1972) J. Macromol. Sci. Phys. BS, 57-77

15 Kogowski, G., Scott, R.M. and Filisko, F. (1980) J. Phys. Chem. 84, 2262-2265

16 Chen, C.-H., Tow, F. and Berns, D.S. (1984) Biopolymers $23,887-896$

17 Almog, R. and Schrier, E.E. (1978) J. Phys. Chem. 84. $2262-2265$
18 Ackermann, T. (1969) in Biochemical Microcalorimetry (Brown, H.D. ed.), pp. 121-148, Academic Press, New York

19 Margetson, S.A., Moore, W.J. and Gibbons, W.A. (1981) Aust. J. Chem. 34, 1373-1394

20 Sadikot, H. and Moore, W.J. (1983) Aust. J. Chem. 36, 33-41

21 Paz-Andrade, M.I., Jones, M.N. and Skinner, H.A. (1976) Eur. J. Biochem. 66, 127-131

22 Lapanje, S., Lunder, M., Vlachy, V. and Skerjane, T. (1977) Biochim. Biophys. Acta 491, 482-490

23 Tanford, C. (1970) Adv. Protein Chem. 24, 1-95

24 von Hippel, P.H. and Wong, K.Y. (1965) J. Biol. Chem. 240, 3909-3923

25 Robinson, D.R. and Jencks, W.P. (1965) J. Am. Chem. Soc. $87,2462-2470$

26 Lapanje, S. Skerjanc, J., Glavnik, S. and Zibret, S. (1978) J. Chem. Thermodynam. 10, 425-433

27 Lapanje, S. (1984) Biopolymers 23, 1943-1950

28 Lee, B. and Richards, F.M. (1971) J. Mol. Biol. 55, 379-400

29 Kresheck, G.C. and Benjamin, L. (1964) J. Phys. Chem. 68, 2476-2486

30 Brostoff, S.W., Reuter, W., Hichens, M., and Eylar, E.H. (1974) J. Biol. Chem. 249, 559-567

31 Privalov, P.L. and Khechinashvili, N.N. (1974) J. Mol. Biol. $86,665-684$

32 Almog, R., Schrier, M.Y. and Schrier, E.E. (1978) J. Phys. Chem. 82, 1703-1707

33 Moscarello, M.A., Neumann, A.W. and Wood, D.D. (1983) Biochim. Biophys. Acta 728, 201-205

34 Smith, R. (1980) Biochemistry 19, 1826-1831 